\title{
Olympic Cities: Regeneration, City Rebranding and Changing Urban Agendas
}

John R. Gold ${ }^{1 *}$ and Margaret M. Gold²

${ }^{1}$ School of Social Sciences and Law, Oxford Brookes University

${ }^{2}$ London Metropolitan Business School, London Metropolitan University

\begin{abstract}
Winning the right to host the Olympic Games is widely regarded as the most significant prize on offer in the never-ending contest between the world's leading cities for prestige and investment. This essay explores the implications and significance of being an Olympic city. After recognising the Olympics as a mega-event with inherent mega-project tendencies, it provides a chronological survey that shows the changing agendas that host cities have brought to bear on staging the Games. The increasing scale of their ambitions is noted, particularly with respect to urban regeneration and city rebranding, while also recognising the financial and human costs involved. The next part throws light on contemporary practice through a study of the proposals for the Lower Lea Valley in London's East End - the site of the future Olympic Park for the 2012 Summer Games. The conclusion suggests an evolving research agenda, framed particularly around the London 2012 Games and the notion of legacy.
\end{abstract}

\section{Introduction}

On 23 March 2007, Prague's 66-member local assembly voted to bid for the right to host the 2016 Summer Olympic Games. Ahead lies competition with the other applicant cities - Chicago, Tokyo, Rio de Janeiro, Madrid, Doha (Qatar) and Baku (Azerbaijan) - in advance of the short-listing process in 2008 and then, if successful, the earnest campaigning before the International Olympic Committee (IOC) holds its final selection meeting in Copenhagen in October 2009. Yet, initial pronouncements from Prague's leaders gave no sense of any real expectation of winning the bid. Given that Prague was a first-time applicant and that London, another European capital, was staging the preceding event in 2012, the city's leadership regarded candidacy for 2016 primarily as an investment, providing much needed experience for staging succeeding bids to hold the Olympics in either 2020 or 2024 (Prague Daily Monitor 2007).

This degree of long-term commitment is not unusual. Numerous applicant cities have fought repeated but unsuccessful campaigns for the 
right to stage the four-yearly Summer Games or, increasingly, their Winter counterparts. The reasons for their resolve lie in the rewards popularly associated with the Olympics. Despite the enormous expenditures on stadia and Games-related facilities, any host city may reasonably expect hefty injections of funds from its share of ticket sales, sponsorships, merchandising and broadcasting rights. Bid teams can also confidently predict that the host city will receive a medium-term stimulus to its construction industry, a brief tourist boom, and a short-term boost in employment at Games venues and in the associated administrative sector. Other anticipated benefits are less dependable but may well occupy a prominent place in the aspirations of the city authorities bidding for the Olympics. These include the hope of that being the Olympic city will boost the urban economy, permanently reposition the city in the global tourist market, promote regeneration, allow the revamping of transport and service infrastructures, create vibrant cultural quarters, and establish a network of high-grade facilities that could serve as the basis for future bids.

Perhaps the most eagerly sought and most elusive benefits, however, arise less from the financial balance sheet than from opportunities for place promotion - the conscious use of publicity and marketing to communicate selective images of towns and regions to a target audience (Gold and Ward 1994, 2; see also Boyle 1997; Ward 1998) - or its more focused incarnations as 'city marketing' (Ashworth and Voogd 1990; Jessop 1998; Kavaratzis 2007) or '(re-)branding' (Berci et al. 2002; Kavaratzis 2004). In a world, where large cities actively compete for recognition and status, the prestige of the Olympics and the sustained attention that they attract provides unparalleled opportunities to make a statement on the world stage. While even constructing a serious bid shows that a city is ambitious for global attention (Ward 2007), capturing the Games allows municipal authorities to undertake long-term activities designed to boost or alter the image of their cities. Yet, changing a city's image in the outside world is far more difficult than, say, the rebranding of a commercial product (Bennett and Savani 2003; Kavaratzis and Ashworth 2005) and the perceived excellence of the Olympic 'brand' as the summit of sporting achievement often fails to rub off on to the city that stages the Games. Certainly, the historic record shows numerous instances where inadequate planning, poor stadium design, the withdrawal of sponsors, political boycotts, heavy cost overruns on facilities, the forced eviction of residents living in areas wanted for Olympic facilities, and subsequent unwanted stadia leave a legacy that tarnishes rather than enhances the reputation of the host city (see Payne 2005; Preuss 2004; Tomlinson 1999).

This essay explores the implications and significance of being an Olympic city against this background. Its first part provides context by recognising the Olympics as the leading example of the genre known as mega-events, while being simultaneously subject to the distinctive financial and logistic characteristics that planning researchers associate with so-called 
'mega-projects'. The second section provides a brief chronological survey that shows how host cities have only recently attached wider ambitions, such as the pursuit of large-scale urban regeneration, to the staging of the Games. While pointing to the endless flexibility of the Olympics as a festival able to absorb changing agendas, it also comments on the heavy financial and human costs involved. The next part throws light on contemporary practice by considering a case-study of the plans for London 2012, looking particularly at the proposals for the Lower Lea Valley - the site of the future Olympic Park in the city's East End. The conclusion suggests an evolving research agenda, framed particularly around the London 2012 Games and the notion of legacy.

\section{Mega-Events and Mega-Projects}

The last 150 years have seen exponential growth of substantial, prolonged and spectacular celebrations of human achievements in the arts, sport and science (Hall 1992; Ritchie 1984). These events vary in type and organisation. Many are so-called 'hallmark events', which become synonymous with the places where they are habitually staged. They include the everlengthening lists of cities staging street circuit road races (e.g. Boston, Buenos Aires, Shanghai and London) or international arts festivals such as those held at Edinburgh, Glastonbury, Roskilde, Chelsea and Salzburg (Boyle 1997; Burns et al. 1986; Gold and Gold 2005; Mattie 1998; Prentice and Andersen 2003; Waterman 1998). These can draw in huge tourist revenues and focus international media attention on the host city, but by virtue of their recurrence are run by cores of permanent staff that utilise well-established sets of practices to stage their events.

In contrast, there are a select number of prestige 'mega-events' that have an ambulatory character and are normally subject to a bidding process by potential hosts. Defined as festivals that achieve sufficient size and scope to affect whole economies and receive sustained global media attention (Getz 1997; Horne and Manzenreiter 2006; Roche 2000), 'mega-events' include the World's Fairs (although these are now of declining influence); the World Cups in soccer, rugby union and cricket; the larger regional sports gatherings (e.g. European Championships, Asian Games and Pan-American Games); and the Olympic Games (e.g. García 2004; Gold and Gold 2005; Jones 2001). In the case of the Olympics, the Lausanne-based IOC holds the sole rights to award its Winter or Summer Games and selects the winning bids after lengthy processes of visits, meetings and consultations. Once awarded, primary responsibility for financing and organising the event then rests with the host.

The Olympics, however, undoubtedly pose special problems over and above those experienced by other mega-events. The first stems from the fact that, unlike hallmark events, the Olympics are extraordinary rather than recurrent occurrences in the life of a city. The IOC favours the 
principle of continental equity, preferring to see the Summer and Winter Games move from continent to continent in line with the founding notions of spreading the Olympic message to the four corners of the earth. The festivals, therefore, migrate between cities in contrasting cultural contexts and, frequently, within different political systems. Most host cities only receive the nomination to stage the Games once, although there are instances when a second or third nomination has been secured after the passage of many years. Hence, while general lessons can be drawn from the experience of predecessors, the organisers inevitably face a steep learning curve by virtue of having to assemble from scratch the teams required to bring the Games to fruition and to establish their specific working practices. Logistical difficulties will emerge, mistakes will be made, and deadlines will be tested.

Second, the Olympics comprise a set of interlocking component festivals rather than a single festival. The group led by Baron Pierre de Coubertin that re-established the Olympics in the 1890s sought to recapture the ethos of the four-yearly festival held for more than a millennium in ancient Greece (see MacAloon 1981; Müller 2000). Their analysis recognised that the classical Games functioned as a panegyris - a festive assembly in which the entire people came together to participate in religious rites, sporting competitions and artistic performance (Phillips and Pritchard 2003). In modern imitation, the IOC decided that the Olympics should have an associated cultural programme, although opinions differed over time as to whether this should be conceived as requiring competitions or merely exhibitions. The Summer and Winter Games (the latter founded in 1924) have also converged with the Paralympic Games for disabled athletes - an event that traces its origins to 1948 and which now takes place in the host city immediately after the main Olympic competitions (Gold and Gold 2007a,c). Compared to other mega-events, this multistranded character inevitably imposes additional strains on resources, adds to logistical problems and, in the case of the cultural Olympics, requires very different planning and administrative skills than those normally associated with sporting events.

Finally, the Olympics are distinctive by virtue of the sheer magnitude of facility and infrastructural provision and by the penchant of organisers to select technologically complex but inherently expensive concepts for stadia design. As a result, the creation of Olympic sites frequently shares the characteristics of construction schemes known as 'mega-projects'. Defined as prestige schemes involving large-scale and high-risk investment over a lengthy period, mega-projects notoriously suffer heavy cost overruns, often fail to deliver the supposed benefits and regularly provoke financial crises (Flyvbjerg et al. 2003). Indeed, the Olympics may suffer more in this respect than other mega-projects by virtue of having an immutable deadline for completion. When works fall behind timetable, this can add cost pressures by forcing organisers to instigate expensive emergency 
building programmes, with round-the-clock working and additional contractors brought in order to get laggard projects back on schedule.

\section{Changing Agendas, Mounting Costs}

These transformations into the status of being a mega-event and a mega-project that had major implications for the host city, however, only occurred gradually (e.g. see Chalkley and Essex 1999; Gold and Gold 2005c; Guttmann 2002). The early Olympics were relatively small festivals staged in existing stadia or using temporary facilities. The first Games of the modern period, Athens 1896, set an early pattern of low expenditure, pressing into service the existing Zappeion building and the restored Panathenian stadium, with new construction restricted to a velodrome, shooting gallery and seating for the swimming events. Paris 1900 and St. Louis 1904 saw the Olympics subsumed as a minor partner into the broader festivities that accompanied International Expositions (World's Fairs). It was not until London 1908 that the Olympics received their own purpose-built stadium, in the shape of the 93,000 spectator capacity White City stadium, built on former agricultural land at Shepherd's Bush. Succeeding Olympics saw the host city continue to supply the necessary facilities for the sporting competitions, embrace the Games by providing venues for hospitality and associated cultural programmes and, from 1924 onwards, start to develop 'Villages' to house athletes and officials (Moragas et al. 1997). Yet, the net effect on the city's wider standing or urban fabric remained minimal. Cities did not seek that advantage and the IOC was keen to prevent profiteering from the Games. Even Berlin 1936, easily the most iconic and politically resonant Summer Games prior to the World War II, had little lasting impact on its host city, despite the creation of the Reichssportfeld, then the world's largest sports complex, in a peripheral district to the northwest of the central area.

Only at Rome 1960, after the end of post-war Austerity, did the full potential of the Olympics as an instrument of urban transformation start to dawn. The organisers capitalised on two areas where relevant facilities were already available: the Foro Italico in the north of the city; and EUR, a district in the south initially designed as a spectacular setting for the (cancelled) 1942 Esposizione Universale di Roma. The former supplied the Stadio Olimpico (originally built in 1936); the monumental and spacious qualities of the latter provided an ideal core for the Olympic facilities, including the Palazzo dello Sport (Sports Palace), the velodrome, the Piscana delle Rose (swimming pool) and the Fontane Sports Zone training area. These 'Olympic areas' made a permanent contribution to the city's sporting and cultural life. Beyond them, the Village at Campo Paroli converted to private-sector housing (Wimmer 1976, 202). Rome also gained from infrastructural improvements undertaken with the Games in mind. These included new roads and bridges built to connect the 
Village to the main Olympic sites, modernisation of the airport, improvement of the telephone, telegraph and radio networks, and initiatives to expand hotel accommodation.

Rome's example was repeated by Summer and, to a lesser extent, Winter Games throughout the 1960s and 1970s. Tokyo 1964 saw major redevelopment projects before the Games, with the city's authorities spending US $\$ 2.7$ billion on works that provided the requisite Olympic facilities and that might help to cater for Tokyo's infrastructural needs up to the year 2000. These included housing, hotel developments, harbour improvements, a monorail system, water supply, sewage disposal and a public health programme (Essex and Chalkley 1998, 195). The Winter Games at Grenoble 1968 saw extensive road construction, airport development and investment in cultural facilities that was designed to facilitate economic growth and promote regional development.

The untroubled sense of combining hosting the Olympics with urban development was, however, soon to reveal strains emanating from the political arena. Mexico City 1968, the first Games held in the developing world, witnessed political protests from groups opposed to Olympic expenditure in the face of competing needs. The repression of student activists and the massacre at the Tlatelolco rally on 2 October, with 260 deaths and over 1200 injuries (Toohey and Veal 2000), showed a darker side to Olympic spectacle (see Barke 2007). Munich 1972 saw the incursion of international terrorism. The undoubted success of the Games in bringing urban regeneration and infrastructural improvement to a city experiencing rapid demographic and economic growth (Essex and Chalkley 1998, 195) was offset by the abiding memory of the hostage-taking by the 'Black September' Palestinian group that eventually led to the death of 11 Israeli athletes and officials, five of the eight terrorists and a German police officer. It effectively ensured that future host cities would have to add a bill for security measures that recognised the Olympics' new, and unwanted, status as a prime terrorist target.

Montreal 1976 saw the Olympics reach their post-war nadir. Chosen as another prime vehicle for the Drapeau regime's attempts to raise the city's international profile after the success of the 1967 World's Fair (Expo '67), Montreal 1976 clearly revealed the Games' mega-project tendencies. Its final shortfall of US $\$ 1.2$ billion, which crippled city finances for the next two decades, was primarily caused by confused political goals, poor financial and logistical management, and severe budget deficits on overambitious buildings. The most notable example was the stadium (Figure 1). The chosen design by the French architect Roger Taillibert, architect of the critically acclaimed Parc des Princes in Paris, embraced an unmistakeable and costly monumentality. In particular, it featured an innovative system for opening and closing the stadium's roof involving a 575-foot (190-m) tower, inclined at 45 degrees, which supported the roof on 26 steel cables. This radical conception produced problems that plagued construction. In 


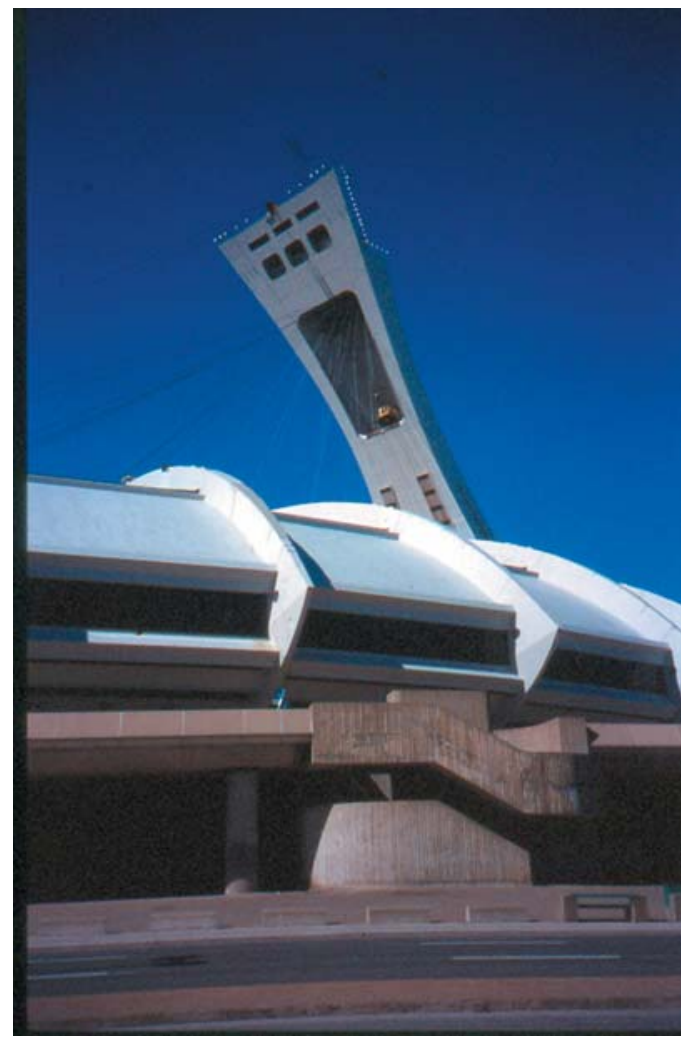

Fig. 1. Taillibert's folly. The Olympic Stadium for Montreal 1976 (architect Roger Taillibert), as seen in October 1998 (Source: Authors' photograph).

fact, the infamous roof was not completed until 1987 and quickly became unusable, leading in the fullness of time to a stadium with an impressive observation tower and a non-retractable roof. The Montreal organisers also favoured unnecessary infrastructural improvements - best exemplified by the remote and expensive international airport at Mirabel, which closed three decades later without ever achieving any useful function.

The damage done to the credibility of the Olympics by Montreal 1976 proved temporary, with the exemplars provided by Los Angeles 1984 and Barcelona 1992 effectively restoring the Summer Olympics as the acme of desire for place promoters and urban regenerators. Briefly, the organisers of the Los Angeles Games provided a new funding model that combined finely tuned commercialism with cost-consciousness in the face of limited public funds. Through judicious use of sponsorship and attention to post-Games use, Los Angeles 1984 made a profit of US\$225 million that was channelled into American sports bodies and programmes and 


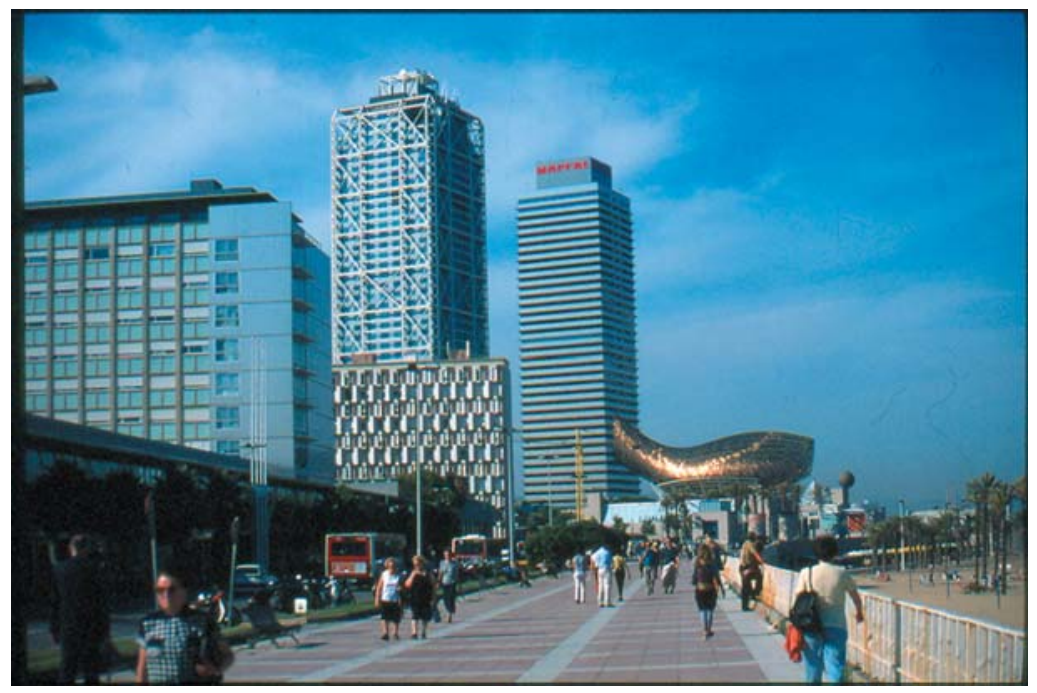

Fig. 2. The Olympic Village, Barcelona 1992. This housed 15,000 participants primarily in two tower blocks, intended for conversion after the Games to a hotel and offices (Source: Authors' photograph).

injected an estimated US $\$ 2.4$ billion into the Southern Californian economy. Barcelona 1992 illustrated what might be achieved by way of Games-related urban regeneration. With a challenging package of measures that countered years of neglect under the Franco regime, Barcelona's planners ploughed $83 \%$ of the total expenditure for the 1992 Games into urban improvements rather than into sport (Varley 1992, 21). The Metro system was extended, the coastal railway rerouted, the airport redesigned and expanded, and the telecommunications systems modernised. There were also 4500 new flats provided by the Olympic Villages, five major nodes of new office development, extensive investment in the cultural sector (especially museums) and 5000 new hotel rooms (Coaffee 2007, 155). Significantly, too, the public gained access to five kilometres of coastline and new beaches (Figure 2).

Yet, while Los Angeles and Barcelona provided the basis of current policy for staging the modern Olympics, the incursion of significant amounts of private investment and creation of private-public alliances to finance the Games proved problematic. This became readily apparent at Atlanta 1996. With Georgia's constitution limiting the role that the city could play and stiff resistance to raising funds from those means within its power (taxing tickets or increasing sales tax), Atlanta 1996 saw a private consortium undertake the organisation of the Games. Its approach rested on a consensus that saw the Games as helpful to Atlanta's place promotional agenda, while also turning place promotion inwards as a means 
of 'galvanising local support and fostering civic pride' (Hubbard and Hall 1998, 8). Business leaders wanted the Games to stimulate economic growth and to carry out urban improvement of a cosmetic nature, with an emphasis on beautification and removal of eyesores, rather than addressing fundamental social questions (Burbank et al. 2001, 82). The promoters stressed that these benefits would accrue without involving tax-payers' money, with Andrew Young, a former mayor of Atlanta who became joint chair of the Organising Committee stating that the Games were 'not a welfare programme (but) a business venture' (cited in Rutheiser 1996, 238; see also Whitelegg 2000).

The resulting Games worked to the benefit of Atlanta's business community, but fell short the ambitions of the leaders of poorer communities, who anticipated benefits regarding job prospects, better roads and improved housing (Maloney 1996, 196). The Olympics also failed to meet the hopes of Atlanta's place marketers, who wanted to broaden the city's image as a cultural centre. Instead, they found themselves having to counter a barrage of negative reports, including criticism for overt commercialism, tawdry ceremonial content (Tomlinson 1999), systems and transport failures and for the ruling regime taking advantage of the Olympics to mount an attack on the city's underclass. Aggressively using city ordinances to 'beautify' areas surrounding Olympic venues, the city displaced poorer residents, closed hostels, and further designed the homeless out of the landscape by means of such measures as sleep-proof benches and intermittent sprinklers (Lenskyj 2000, 138-139; Burbank et al. 2001, 113). Not all, however, was negative. Although the post-Games partial demolition of the 85,000 -seater Olympic Stadium to create a new 47,000-seater stadium for the Atlanta Braves baseball team may have been partly designed to prevent the owner (Ted Turner) from relocating the team away from Atlanta, the action spared the city from having an expensive and underused athletics stadium - as was subsequently the case with both Sydney and Athens.

Response to the commercialism of Atlanta coupled with the IOC's consciousness of the spiralling cost of the Olympics subsequently focused attention on environmental sustainability and latterly 'sustainable legacy' albeit with no huge success to date. Sydney 2000, for example, provided the opportunity to address the problems of heavily polluted brownfield land by building the Olympic Park at Homebush Bay, approximately 9 miles $(14 \mathrm{~km})$ upstream from Sydney's city centre. Although immediate post-Games analysis (e.g. Haynes 2001) argued the success of the Olympics in achieving dramatic infrastructural and environmental improvement to a blighted area at roughly neutral economic cost (Gold and Gold 2007b, 45), subsequent reappraisal views the matter less favourably. In particular, questions are asked as to whether the decontamination of toxic waste sites had been fully tackled and about the viability of the heavily underused and loss-making Olympic Stadium (latterly the Telstra Stadium). 
Athens 2004 recorded a similar experience. Although Athenians witnessed the reconstruction of their city's tourist infrastructure, creation of an Archaeological Park, and investment in the cultural sector and public transport, wider questions soon surfaced about the sustainability of the Olympic facilities. Despite its landmark buildings being intended to symbolise the new Athens, the Olympic Sports Complex at Maroussi remains heavily underused and inaccessible to the public except when soccer matches are held at the stadium. The other complexes at Faliro and Helleniki struggle to find alternative uses. All face mounting debts because repayments on borrowing and the costs of security and maintenance still have to be met. Presented with this evidence, the questions of how to turn the lavish and large-scale facilities required for the Summer Olympics into sustainable legacy for the host city now preoccupy planners of future Olympics almost as much as issues linked to the preparation of the Games themselves.

Confirmation of this point is seen in the 'green credentials' claimed for Beijing 2008, for which the facilities now approach completion. The Beijing Games balance the promotional and regenerative interests of both host nation and city. Always intended to act as a historic marker to proclaim China's re-emergence on to the world stage as an economic and military power, the Games represent a joint effort by the Chinese national government, which seeks to absorb the Olympics into national economic regeneration, and a city authority keen to undertake urban regeneration. Most investment has been channelled into Beijing itself, with an Olympic Park covering an area of 1215 ha, including an 80,000-seater stadium, 14 gymnasia, an athletes' Village and an international exhibition centre, surrounded by a 760-ha forest and greenbelt (Cook 2007, 291). Regenerative plans include construction of new hotels, road infrastructure, expansion of the international airport and much needed investment in parks and water recycling centres. At the same time, it is again clear that, as with many previous Games, the Olympics have become part of the rationale for demolition of so-called 'substandard housing', in which the criteria used to define dilapidation have a remarkable habit of yielding sites in places wanted for redevelopment. This process of demolition particularly threatens the old hutong and siheyuan areas - comprising single storey, often dilapidated houses arranged along narrow lanes - that find themselves standing in the way of the grand structures of an internationalised Olympic metropolis (Cook 2006). Indeed, the Geneva-based human rights group, the Centre on Human Rights and Evictions, estimates that a total of 1.5 million Beijing residents will have been evicted by the time that the Opening Ceremony takes place (Engel 2007).

\section{London 2012}

The supreme malleability of the Olympic festival, readily able to absorb the varying agendas held by the municipal authorities ruling the cities in 
which the Games are held, continues to be a feature of planning for future events. The 2012 London Games will retain the trajectory of large-scale intervention in search of sustainable legacy (Evans 2007). Although the organisers will use a series of existing venues throughout the capital for particular sports - such as Wembley Stadium (football), Wimbledon (tennis) and Hyde Park (riding events) - the locations for most of the other venues would be concentrated in an Olympic Park situated in a regenerated portion of the Lower Lea Valley.

A full account of the evolution of London's 2012 bid, which dates back to 1995 (Shoval 2002, 592-593), lies outside the scope of this article (see Evans 2007; Lee 2006), but three features merit further discussion. First, the lack of any real conviction that London would overhaul Paris, the long-time favourite, in the contest to gain the nomination for 2012 would prove to have important implications for financing and marketing the Games (Gold 2007). Proceeding on this assumption, for example, the London bid team skimped on providing accurate costs, which quickly proved woefully inaccurate. Whereas the bid document forecast a $£ 2.375$ billion capital budget and $\mathcal{E}_{1.5}$ billion operating budget, to be supplemented by additional financing of transport and site infrastructure, the headline figure had already risen to $£ 9.325$ billion by May 2007 (Gold and Gold 2007c, 318). Among elements absent from the original costs were policing and security ( $£ 600$ million), value-added tax ( $£ 836$ million) and a hefty programme contingency cost of $\mathcal{f}^{2.747}$ billion added at the Treasury's behest to cover cost overruns. Equally, lack of belief that the Games would come to London served to reduced levels of opposition. Some ideological resistance was apparent, but the Olympic good news story and the outsider status of the London bid lessened the negative press (Evans 2007, 308). Even within the designated boundaries of the Olympic Park, opposition remained local and ill-coordinated until after the bid had been won.

Second, the sense that the nomination was destined for Paris effectively changed the terms in which the bidding team conceived their task, viewing the bid partly as an exercise in city marketing and partly as a longer-term statement of enduring principles. As Evans (2007, 299) noted, London's bid document placed 'greatest emphasis ... on the legacy and after-affects of the Olympic leverage opportunity, rather than the event, its content and purpose.' The document, for instance, outlined a four-yearly programme for the Cultural Olympiad. It also made considerable strides towards integrating the Paralympics into the Games' planning and to offering the notion of a barrier-free city (Gold and Gold 2007a). The theme of inclusiveness also extended to ethnicity. The bid strove hard to offer a rebranding of London away from being identified by its historic heritage to that of a diverse city with a vibrancy based on its multiculturalism. Much was made of London's diverse ethnic identities and the multicultural character of the five 'Olympic boroughs' in the East 


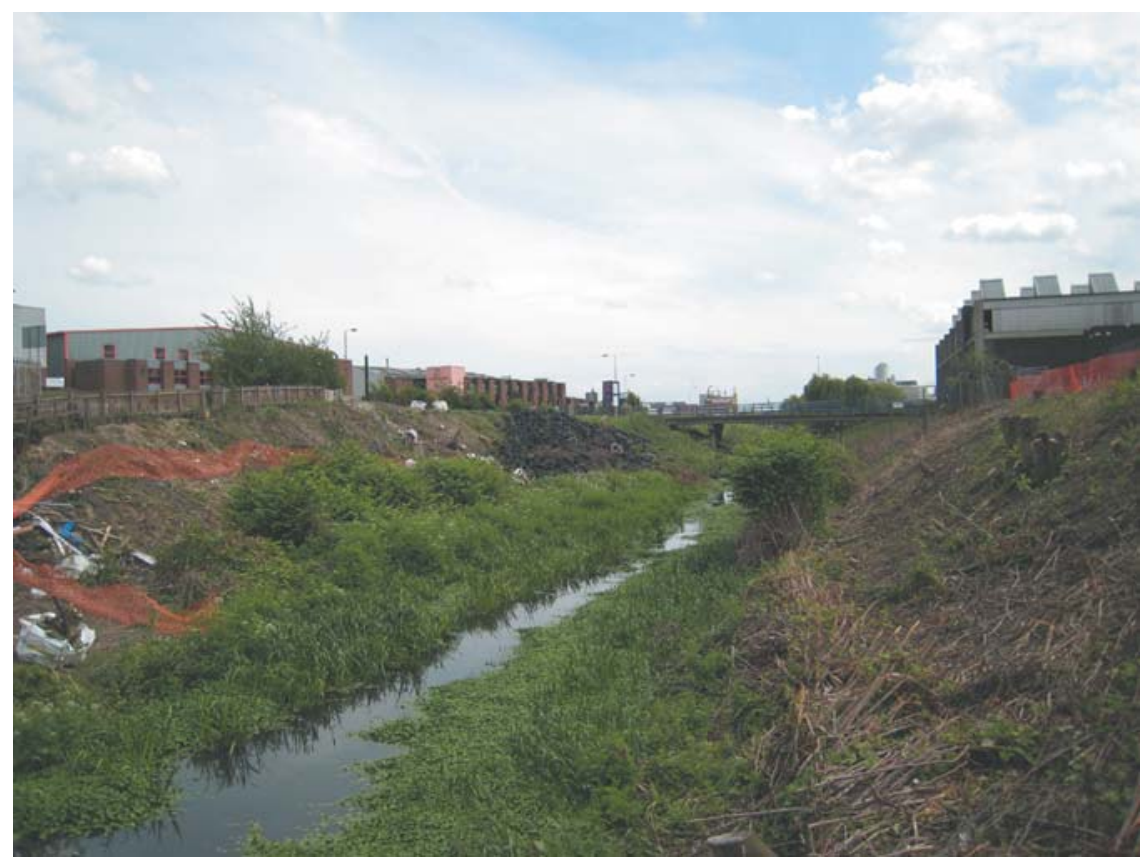

Fig. 3. The Pudding Mill River, tributary of the River Lea, bisecting the southern part of the future Olympic Park. After clearance, the 80,000-seater Olympic Stadium will be located to the left and the warm-up athletics tracks to the right (May 2007) (Source: Authors' photograph).

End (Greenwich, Hackney, Newham, Tower Hamlets, Waltham Forest), where the main events would be housed. The theme of the world coming to London to meet the world was carefully fostered in marketing the notion of London 2012 and, indeed, was tellingly picked up in the presentation made at the IOC's final selection meeting in Singapore in July 2005.

Finally, the bid offered to concentrate most activities in a nucleated Park, a known preference of the IOC, and addressed the growing concern for sustainable legacy by using the mega-event as a vehicle for regenerating one of the largest areas of brownfield land in the London region. Situated on the city's northeast margins, the Lea Valley experienced the marginality that stemmed from it being a place to avoid, having been used as a site for noxious industries and a perennial dumping ground for waste products (Figure 3). Yet, its character as an elongated strip of open space crisscrossed by water channels has also sparked the imagination. For example, the influential Greater London Plan saw it as supplying the 'opportunity for a great piece of constructive, preservative and regenerative planning' (Abercrombie $1945,105)$, with the possibility of a 'green wedge' that would serve as a 'lung' for the people of London. For the bidding team, too, it had the immense advantage of being adjacent to the central urban area without having a large residential population that Olympic developments would displace. 
As awarded in July 2005, the plan envisaged the complete transformation of the portion of the lower Lea Valley between Stratford and Hackney into a 600-ha Olympic Park (London Organising Committee for the Olympic Games [LOCOG] 2004). This would house the main 80,000seater stadium and participant's Village, together with the Paralympic tennis and archery facilities, hockey centre, velodrome, fencing hall, handball arena, aquatic centre, basketball arena, media centres and warm-up facilities. The area would be served by a major transport interchange, located $1 \mathrm{~km}$ to the east of the stadium at Stratford and served by underground, national rail, Eurostar and bus services.

The lack of settlement in the Olympic Park, coupled with the fact many of the 300 displaced businesses represented small firms with minimal political clout, supplied the impression that regeneration of a physically blighted area would take place with little human cost (Engel 2007). That impression has been actively encouraged by developers, because it allows a conveniently dystopic image against which to juxtapose the shining future apparently on offer. The plans anticipate the revalorisation of the Lower Lea Valley through its environmental transformation, renewed social capital and general associations with the Olympics. Although popular preferences are for creation of new family houses rather than flats - of which there is currently an adequate supply given the proximity to the adjacent Docklands regenerations - the plans seek to attract residents to additional 3600 flats in the Olympic Village and 9000 in the Olympic Park area as a whole. Beyond development of the Olympic Park, work has already started on projects that will transform 73 ha of dereliction into Stratford City - a $\mathcal{E}_{4} 4$ billion metropolitan centre in East London, with more than 100 shops, three big department stores, cafés, schools, hotels, parks and health centres that will supply employment for an additional 30,000 workers (London Borough of Newham 2007). The Press Centre would serve as the basis for a new cultural and media development. Taken together, these initiatives promise to turn this area into one of Europe's largest urban regeneration sites (Figure 4).

Those, at least, are the plans, although previous experience reveals the difficulties associated with after-Games use. It is true that the Olympic boroughs suffer considerable social deprivation and that Games will permit a comprehensive approach to regeneration rather than the previous 'patchwork' of funding schemes (Audit Commission 1989). It is also probable that assiduous quarrying of the Olympic brand will have some impact on the image of the five boroughs and perhaps assist local businesses. Yet, just as there is doubt that the Olympics will bring the forecast employment benefits to the surrounding areas due to skills deficiencies, so too are there reservations as to whether the developments will address the needs of the existing community or encourage gentrification. Experience also highlights the gaps between promises and delivery. Infrastructural and environmental improvements - elements that can make a major difference 


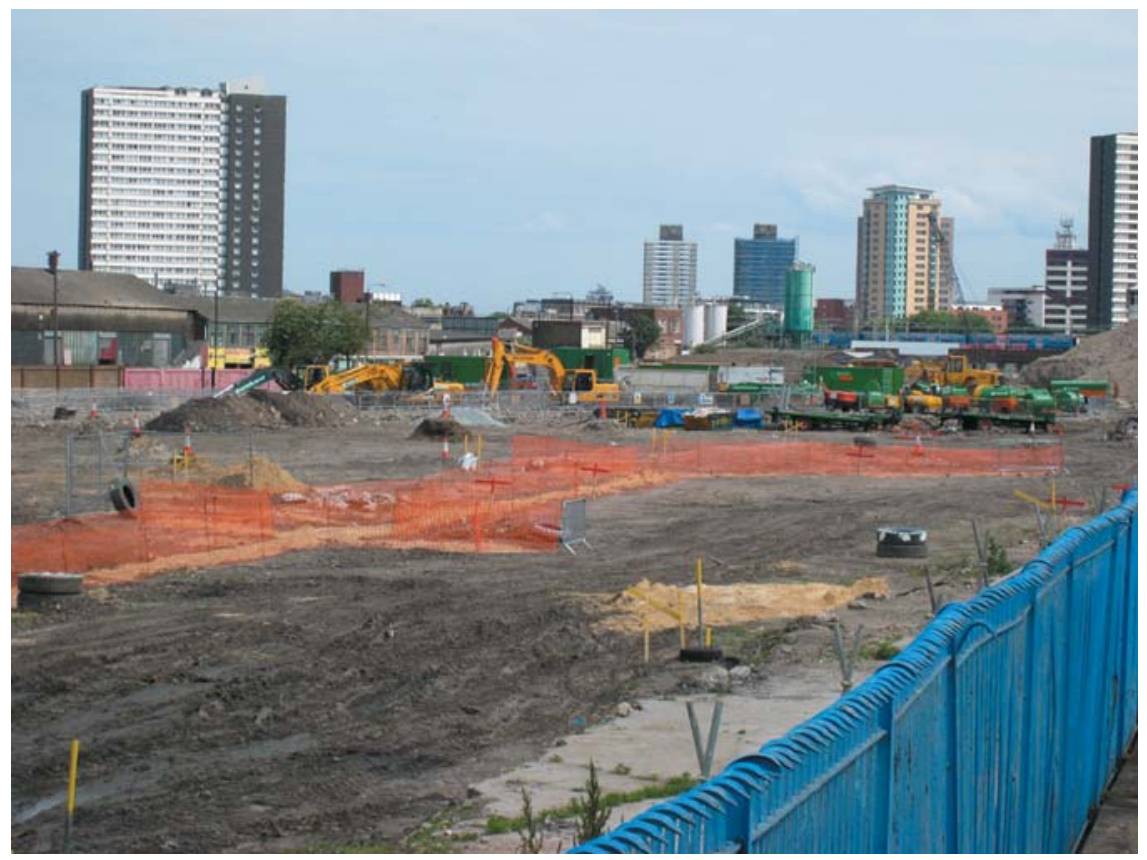

Fig. 4. Clearance work for the Stratford City development project, May 2007 (Source: Authors' photograph).

to post-Games use - may experience cost-saving modifications or even abandonment. The recent Summer Games in Sydney and Athens, for example, both raised questions as to whether decontamination of toxic land had been properly tackled; an issue of continuing relevance for London. Budgetary problems, too, normally lead to cutbacks for lower profile elements. For instance, London's ambitious cultural programme, designed to supply national signature events and smaller projects at regional or local level over the four years of the Olympiad (LOCOG 2007, 6), remains particularly vulnerable.

\section{Conclusion}

The question of legacy, so important for London's bid for the 2012 Games, is also central to any research agenda deriving from the modern Olympics. Addressing the notion of 'legacy', however, immediately encounters the problem that it is an evolving concept that was not part of the original vision for the revival of the Games. Official records show the first significant mention of the term occurred in 1956 in relation to the Melbourne Games (McIntosh 2003, 450), with the idea of a physical legacy only becoming a significant factor from Rome 1960 onwards. As the 20th century wore on, preoccupation with infrastructural change and city marketing progressively eroded the attention paid to the sporting 
dimension. Scale exerted an intoxicating appeal, with the IOC seemingly developing a partiality for supporting comprehensive interventions that somehow mirrored, and possibly served to justify, the steadily increasing size and demands of the Games. A proposal that offered a striking regenerative transformation such as London's Lea Valley might serve as a symbol of the positive virtues of staging the Olympics and act as a fig leaf for the enormous expenses required and incurred.

A particular goal for research during the years leading to and after 2012, therefore, is to examine the reality of legacy in light of the forecasts. Eleven areas of inquiry, which are partly anticipated by the latest policy document on this subject (Department of Culture Media and Sport [DCMS] 2007), would seem particularly germane in this respect:

- to investigate whether patterns of public participation in sport prove to alter significantly, both in the Olympic boroughs and further afield;

- to see whether appropriate skills have been successfully inculcated in a part of London where low levels of achievement are often highlighted and where the pace of economic change requires new skills sets for future employment prospects;

- to examine the extent to which city marketing has delivered any significant rebranding of London and the UK as a "creative, inclusive and welcoming place to live in, visit, and for business' (DCMS 2007, 4);

- to assess the progress of cultural tourism and the extent to which it has benefited from the four-yearly Cultural Olympiad associated with the Games;

- to evaluate improvements in cultural infrastructure, audience development and participation levels in the arts as a result of the Cultural Olympiad;

- to analyse whether or not Games-related development delivers a regenerated Lea Valley and East London and draws to related regeneration projects, for example, in the Thames Gateway;

- to examine the extent to which the rhetoric of environmentalism successfully translates into provision for sustainable living, especially in the Olympic Park;

- to evaluate whether the improved transport infrastructure, especially public transport, has not only benefited East London and improved its connections to the rest of London and beyond, but also whether the Olympics delivers tangible improvements in public transport for Londoners generally;

- to assess whether London has become a more user-friendly city for the disabled, in which greater understanding is matched by a barrier free environment;

- to investigate whether the sports complexes constructed for the Olympics gain significant post-Games usage and not, as with other recent Olympics, become white elephants; and

- to examine the extent of benefits for cities and regions outside London, particularly when recalling initial concerns that benefits from so large a project should not be confined to the capital. 
This list is not exhaustive but covers many of the key areas of Olympic activity. Addressing it would certainly help to supply firmer evidence for the ongoing debate over legacy that, if left to official sources, would inevitably accent the positive and gloss over the real balance sheet if that should prove to be adverse.

\section{Short Biographies}

Dr. John R. Gold is Professor of Urban Historical Geography and a member of the Institute for Historical and Cultural Research at Oxford Brookes University, Oxford, UK. A frequent radio and television broadcaster, he is the author or editor of 14 books on architectural and cultural subjects. The four most recent are Representing the Environment (Routledge, 2004, with George Revill), Cities of Culture (Ashgate, 2005, with Margaret Gold), The Practice of Modernism: Modern Architects and Urban Transformation, 1954-1972 (Routledge, 2007), and Olympic Cities: City Agendas, Planning, and the World's Games, 1896-2012 (Routledge, 2007, edited with Margaret Gold).

Margaret M. Gold is Senior Lecturer in Arts and Heritage Management at London Metropolitan University and a member of the University's International Institute for Culture, Tourism and Development. She is Course Leader for the BA in Arts Management and the MA in Arts and Heritage Management. Her books include Imagining Scotland (Scolar Press, 1995) and Cities of Culture (Ashgate, 2005) and editor of Olympic Cities: City Agendas, Planning, and the World's Games, 1896-2012 (Routledge, 2007) - all joint with John R. Gold. Her current research interests include heritage interpretation and cultural festivals.

\section{Note}

^ Correspondence address: John R. Gold, School of Social Sciences and Law, Oxford Brookes University, Gipsy Lane Campus, Headington, Oxford OX3 0BP, UK. E-mail: jrgold@brookes.ac.uk.

\section{References}

Abercrombie, P. (1945). Greater London Plan 1944. London: His Majesty's Stationery Office.

Ashworth, G. J., and Voogd, H. (1990). Selling the city: marketing approaches in public sector urban planning. London: Belhaven Press.

Audit Commission. (1989). A review of urban programme and regeneration schemes in England. London: HMSO.

Barke, M. (2007). Mexico City 1968. In: Gold, J. R. and Gold, M. M. (eds) Olympic cities: city agendas, planning, and the world's games, 1896-2012. Studies in History, Planning and the Environment Series. London: Routledge, pp. 183-196.

Bennett, R., and Savani, S. (2003). The rebranding of city places: an international comparative investigation. International Public Management Review 4 (2), pp. 70-87.

Berci, F., et al. (2002). City branding: image building and building images. Rotterdam, The Netherlands: NAi Publishers. 
Boyle, M. (1997). Civic boosterism in the politics of local economic development - in 'institutional positions' and 'strategic orientations' in the consumption of hallmark events. Environment and Planning A 29 (11), pp. 1975-1997.

Burbank, M. J., Andranovitch, G. D., and Heyling, C. H. (2001). Olympic dreams: the impact of mega-events on local politics. Boulder, CO: Lynne Rienner.

Burns, J. P. A., Hatch, J. H., and Mules, T. J. (eds) (1986). The Adelaide grand prix: the impact of a special event. Adelaide, Australia: Centre for South Australian Economic Studies.

Chalkley, B., and Essex, S. (1999). Urban development through hosting international events: a history of the Olympic Games. Planning Perspectives 14, pp. 369-394.

Coaffee, J. (2007). Urban regeneration and renewal. In: Gold, J. R. and Gold, M. M. (eds) Olympic cities: city agendas, planning, and the world's games, 1896-2012. Studies in History, Planning and the Environment Series. London: Routledge, pp. 151-162.

Cook, I. G. (2006). Beijing as an 'internationalized metropolis'. In: Wu, F. (ed.) Globalisation and China's cities. London: Routledge, pp. 63-84.

—. (2007). Beijing 2008. In: Gold, J. R. and Gold, M. M. (eds) Olympic cities: city agendas, planning, and the World's Games, 1896-2012. Studies in History, Planning and the Environment Series. London: Routledge, pp. 183-196.

DCMS (Department of Culture Media and Sport). (2007). Our promise for 2012: how the UK will benefit from the Olympic Games and Paralympic Games. London: DCMS.

Engel, M. (2007). Olympic losers. Financial Times Magazine 14-15 July, p. 8.

Essex, S., and Chalkley, B. (1998). Olympic Games: catalyst of urban change. Leisure Studies 17, pp. 187-206.

Evans, G. (2007). London 2012. In: Gold, J. R., and Gold, M. M. (eds) Olympic cities: city agendas, planning, and the world's games, 1896-2012. Studies in History, Planning and the Environment Series. London: Routledge, pp. 298-317.

Flyvbjerg, B., Bruzelius, N., and Rothengatter, W. (2003). Megaprojects and risk: an anatomy of ambition. Cambridge, UK: Cambridge University Press.

García, B. (2004). Urban regeneration, arts programming and major events: Glasgow 1990, Sydney 2000 and Barcelona 2004. International Journal of Cultural Policy 10, pp. 103-118.

Getz, D. (1997). Event management and event tourism. New York: Cognizant Communications Corporation.

Gold, J. R., and Ward, S. V. (eds) (1994). Place promotion: the use of publicity and marketing to sell towns and regions. Chichester, UK: John Wiley \& Sons.

Gold, J. R. (2007). Place promotion, rebranding and the moving frontier of selling cities. First International Conference on the Geography of Europe (EUGEO 2007), European Association of Geographical Societies, August 2007.

Gold, J. R., and Gold, M. M. (2005). Cities of culture: staging international festivals and the urban agenda, 1851-2000. Aldershot, UK: Ashgate Press.

- (2007a). Access for all: the rise of the Paralympics within the Olympic movement. Journal of the Royal Society for the Promotion of Health 127 (3), pp. 133-141.

- (2007b). Athens to Athens: the Summer Olympics. In: Gold, J. R., and Gold, M. M. (eds) Olympic cities: city agendas, planning, and the world's games, 1896-2012. Studies in History, Planning and the Environment Series. London: Routledge, pp. 15-47.

- (eds) (2007c). Olympic cities: city agendas, planning, and the world's games, 1896-2012. Studies in History, Planning and the Environment Series. London: Routledge.

Guttmann, A. (2002). The Olympics: a history of the modern games, 2nd ed. Urbana, IL: University of Illinois Press.

Hall, C. M. (1992). Hallmark tourist events: impacts, management, planning. London: Belhaven.

Haynes, J. (2001). Socio-economic impact of the Sydney 2000 Olympic Games. Lucerne, Switzerland: Olympic Studies Centre/Universitat Autònoma de Barcelona.

Horne, J., and Manzenreiter, W. (eds) (2006). Sports mega-events: social scientific analyses of a global phenomenon. Oxford, UK: Blackwell.

Hubbard, P., and Hall, T. (1998). The entrepreneurial city and the 'new urban politics'. In: Hall, T. and Hubbard, P. (eds) The entrepreneurial city. Chichester, UK: Wiley, pp. 1-23.

Jessop, B. (1998). The enterprise of narrative and the narrative of enterprise: place marketing and the entrepreneurial city. In: Hall, T. and Hubbard, P. (eds) The entrepreneurial city. Chichester, UK: Wiley, pp. 77-99. 
Jones, C. (2001). Mega-events and host-region impacts: determining the true worth of the 1999 Rugby World Cup. International Journal of Tourism Research 3 (3), pp. 241-251.

Kavaratzis, M. (2004). From city marketing to city branding: towards a theoretical framework for developing city brands. Place Branding 1 (1), pp. 58-73.

- (2007). City Marketing: the past, the present and some unresolved issues. Geography Compass 1 (3), pp. 695-712.

Kavaratzis, M., and Ashworth, G. J. (2005). City branding: an effective assertion of identity or a transitory marketing trick? Tijdschrift Voor Economische en Sociale Geografie 96 (5), pp. 506-514.

Lee (2006). The race for the 2012 Olympics. London: Virgin Books.

Lenskyj, H. J. (2000). Inside the Olympic industry: power, politics and activism. Albany, NY: State University of New York Press.

LOCOG (London Organising Committee for the Olympic Games). (2004). London 2012: candidate file, London: LOCOG. Reproduced at [online]. Retrieved on 14 April 2006 from http://www.london2012.com/en/news/publications/Candidatefile/Candidatefile.htm

—. (2007). Culture update. [online]. Retrieved on 1 August 2007 from http://www. london2012. com/NR/rdonlyres/00006717-77A7-4285-90AD-A1896E051202/0/Cultureupdate210607.pdf

London Borough of Newham. (2007). Regeneration projects: stratford city. [online]. Retrieved on 14 June 2007 from http://www.newham.gov.uk/Services/RegenerationProjects/AboutUs/ stratfordcity.htm

MacAloon, J. J. (1981). This great symbol: Pierre de Coubertin and the origins of the modern Olympic Games. Chicago, IL: University of Chicago Press.

Maloney, L. (1996). Barcelona 1992: the Games of the 25th Olympiad. In: Findling, J. E. and Pelle, K. D. (eds) Historical dictionary of the modern Olympic movement. Westport, CN: Greenwood Press, pp. 185-193.

Mattie, E. (1998). World's fairs. New York: Princeton Architectural Press.

McIntosh, M. J. (2003). The Olympic bid process as a starting point of the legacy development. In: Moragas, M., de Kennett, C. and Puig, N. (eds) The legacy of the Olympic Games 1984-2000. Lausanne, Switzerland: International Olympic Committee, pp. 450-456.

Moragas, M., de Llines, M., and Kidd, B. (eds) (1997). Olympic Villages: a hundred years of urban planning and shared experiences. Lausanne, Switzerland: International Olympic Committee.

Müller, N. (ed.) (2000). Pierre de Coubertin, 1893-1937: Olympism, selected writings. Lausanne, Switzerland: International Olympic Committee.

Payne, M. (2005). Olympic turnaround: how the Olympic Games stepped back from the brink of extinction to become the world's best known brand-and a multi-billion dollar global franchise. Twyford, UK: London Business Press.

Prague Daily Monitor (2007). Olympics 2016: Prague says it won't be expensive. [online]. Retrieved on 14 October 2007 from http://www.praguemonitor.com/en/171/prague_news/12173

Phillips, D. J., and Pritchard, D. (eds) (2003). Sport and festival in the ancient Greek world. Swansea, UK: Classical Press of Wales.

Prentice, R., and Andersen, V. (2003). Festival as creative destination. Annals of Tourism Research 30 (1), pp. 7-30.

Preuss, H. (2004). The economics of staging the Olympics: a comparison of the Games, 1972-2008. Cheltenham, UK: Edward Elgar.

Ritchie, J. R. B. (1984). Assessing the impact of hallmark events. Journal of Travel Research 23, pp. $2-11$.

Roche, M. (2000). Mega-events and modernity: Olympics and expos in the growth of global culture. London: Routledge.

Rutheiser, C. (1996). Imagineering Atlanta: the politics of place in the city of Atlanta. London: Verso.

Shoval, N. (2002). A new phase in the competition for the Olympic Gold: the London and New York bids for the 2012 Games. Journal of Urban Affairs 24 (5), pp. 583-599.

Tomlinson, A. (1999). The Game's up: essays in the cultural analysis of sport, leisure and popular culture. Aldershot, UK: Ashgate.

Toohey, K., and Veal, A. J. (2000). The Olympic Games: a social science perspective. Wallingford, UK: CAB International Publications.

Varley, A. (1992). Barcelona’s Olympic facelift. Geographical Magazine 64 (July), pp. 20-24. 
Ward, S. V. (1998). Selling places: the marketing and promotion of towns and cities 1850-2000. London: E \& FN Spon.

- (2007). Promoting the Olympic city. In: Gold, J. R. and Gold, M. M. (eds) Olympic cities: city agendas, planning, and the world's games, 1896-2012. Studies in History, Planning and the Environment Series. London: Routledge, pp. 120-137.

Waterman, S. (1998). Carnivals for élites? The cultural politics of arts festivals. Progress in Human Geography 22 (1), pp. 54-74.

Whitelegg, D. (2000). Going for gold: Atlanta's bid for fame. International Journal of Urban and Regional Research 24, pp. 801-817.

Wimmer, M. (1976). Olympic buildings. Leipzig, UK: Editions Leipzig. 